NBER WORKING PAPER SERIES

\title{
CAPITALIZATION OF CAPITAL GAINS TAXES: EVIDENCE FROM STOCK PRICE REACTIONS \\ TO THE 1997 RATE REDUCTION
}

\author{
Mark H. Lang \\ Douglas A. Shackelford \\ Working Paper 6885 \\ http://www.nber.org/papers/w6885
NATIONAL BUREAU OF ECONOMIC RESEARCH 1050 Massachusetts Avenue
Cambridge, MA 02138
January 1999

This paper has benefited from comments by Julie Collins, Ilia Dichev, Merle Erickson, Bill Gentry, Glenn Hubbard, Deen Kemsley, Ed Maydew, Lillian Mills, Mary Margaret Meyers, Joel Slemrod, Steve Slezak, Peter Wysocki, and workshop participants at the NBER's Summer Institute, University of Arizona, University of Michigan, and the University of Pennsylvania, and from research assistance by Judy Land. The views expressed here are those of the author and do not reflect those of the National Bureau of Economic Research.

๑ 1999 by Mark H. Lang and Douglas A. Shackelford. All rights reserved. Short sections of text, not to exceed two paragraphs, may be quoted without explicit permission provided that full credit, including ${ }^{\mathbb{O}}$ notice, is given to the source. 
Capitalizations of Capital Gains Taxes: Evidence from

Stock Price Reactions to the 1997 Rate Reduction

Mark H. Lang and Douglas A. Shackelford

NBER Working Paper No. 6885

January 1999

JEL No. H24, G12, G35, G14

\begin{abstract}
We empirically document that stock prices moved inversely with dividend yields during the May, 1997 week, when the White House and Congress agreed on a budget accord that included a reduction in the capital gains tax rate. The share prices of firms not currently paying dividends increased approximately 6 percentage points more over a five-day window than the share prices of other firms. Among firms paying dividends, the change in share prices was decreasing in dividend yields.

The results are consistent with at least two related explanations. First, to the extent a stock's returns are expected to be taxed as capital gains, a reduction in the expected capital gains tax rate enhances the attractiveness of the investment to investors. Second, to the extent a firm's stock is held by shareholders subject to the capital gains tax, a reduction in the expected capital gains tax rate increases its market value. The findings present evidence consistent with neither a sell-off of appreciated securities following the rate reduction nor a reduction in the compensation for capital gains taxes that selling shareholders demand from buyers. The upward price pressure around the accord dominated any downward price pressure imposed by these factors.
\end{abstract}

Mark H. Lang

Kenan-Flager Business School

University of North Carolina

Campus Box 3490, McColl Building

Chapel Hill, NC 27599-3490

Douglas A. Shackelford

Kenan-Flager Business School

University of North Carolina

Campus Box 3490, McColl Building

Chapel Hill, NC 27599-3490

and NBER

doug_shack@unc.edu 


\section{Capitalization of Capital Gains Taxes: Evidence from Stock Price Reactions to the 1997 Rate Reduction}

\section{Introduction}

This paper examines whether stock prices are discounted for potential capital gains taxes. The extent to which shareholder taxes affect stock prices is central to firm valuation and tax policy and has long intrigued scholars in economics, finance, and accounting. To date, the controversy has largely centered on whether dividend taxes are capitalized in equity values. This paper extends the discussion to consider whether capital gains taxes are capitalized. The equity capitalization of capital gains taxes is assessed by evaluating stock price reactions around a likely change in expected capital gains tax rates, namely the May 1997 budget accord that led to a reduction in the long-term capital gains tax rate from 28 percent to 20 percent. $^{1}$

Shareholders can pay capital gains taxes on trades in the secondary market, share repurchases, and liquidating distributions. Because dividends reduce current stock prices and future liquidation values, reductions in the expected capital gains tax rate should be particularly value-enhancing to firms that do not pay dividends or pay low dividends, ceteris paribus. If investors expect cross-sectional differences in the proportion of earnings ultimately to receive capital gains treatment (e.g., because of dividend policy variation), company valuation should vary cross-sectionally, based on differences between ordinary income and capital gains rates. The purpose of this study is to determine whether such cross-sectional valuation differences can be detected when expected capital gains tax rates change.

\footnotetext{
${ }^{1}$ Realizations from capital transactions are subject to differing tax treatments depending on whether they are gains or losses and how long the investor has owned the property. Throughout the paper, references to the current capital gains tax rate mean the most favorable long-term capital gains tax rate applied to net long-term capital gains.
} 
To date, few studies have investigated the effect of capital gains taxes on stock prices and their findings have been inconclusive. Inconsistent with capital gains tax capitalization, Amoako-Adu, Rashid and Stebbins (1992) report stock prices reactions did not vary across dividend yields when the Canadian government introduced a $\$ 500,000$ lifetime capital gains exemption in 1985. Conversely, consistent with capital gains tax capitalization, they report that high-dividend yield firms experienced a significantly smaller price decrease than low dividend yield firms when the exemption was reduced to $\$ 100,000$ in 1987 . They do not reconcile the conflicting findings. One possible explanation is that the second test is more powerful because the second exemption amount is more binding for the marginal investor than the first.

Two concurrent papers examine capital gains tax capitalization using a residual-income valuation model (Ohlson (1995)). Harris and Kemsley (1999) infer that equity is discounted for dividend taxes because the coefficient on retained earnings (their proxy for future dividends) in their valuation model is less than the coefficient on other book value. If capital gains taxes also are capitalized, they reason that the coefficient on retained earnings should vary with the firm's dividend yield and should vary depending on whether the firm repurchases its shares. No clear patterns of variation emerge.

Collins and Kemsley (1998) extend the Harris-Kemsley model to incorporate the capital gains taxes arising from secondary trading. Examining 46,584 observations from 1975-1994, they regress stock prices on book value, earnings, dividends, and the interactions of the maximum statutory capital gains tax rate with earnings and dividends. Consistent with their predictions, they report that the coefficient on the earnings (dividend) interaction is negative (positive). They interpret the coefficients on the interaction terms as evidence that capital gains 
taxes reduce firm value through their effect on the valuation of earnings, but that firms can offset this negative valuation effect by paying dividends.

However, Collins and Kemsley (1998) potentially suffer from a lack of variation in the maximum statutory capital gains tax rates. The capital gains tax rates were 28 percent in all years, except 1975-1978, when they were 35 percent, and 1982-1986, when they were 20 percent. Thus, the results are driven solely by differences between the study's first four years and the five years following the 1981 rate reduction and rely critically on controls for other sources of variation between these two periods. Furthermore, in years of legislative change in the rates (i.e., 1978, 1981, and 1986), investors likely began to impound the capital gains tax rate before it became effective in the following year. Moreover, to the extent prices are set by the expected capital gains tax rate, rather than the current statutory rate, it becomes difficult to identify the relevant rate in several non-change years that were filled with speculation about possible changes in the capital gains tax rate.

This paper avoids these research design problems by adopting a capital markets event study methodology to test whether share prices reflect anticipated capital gain taxes. On May 2, 1997, the Clinton Administration and the Republican Congressional leaders announced agreement concerning the general features of the fiscal 1998 federal budget. Among other changes, the accord included an unspecified reduction in the maximum statutory capital gains tax rate for individuals. No adjustment in the ordinary tax rate on dividend income was proposed. This event potentially offers a more powerful test of capital gains tax capitalization than the exemptions examined by Amoako-Adu, et al. (1992) because the capital gains tax rate affects all individual investors, no matter their amount of capital gains. 
If expected capital gains taxes are capitalized in equity prices and news of the agreement had not leaked to the market, then stock prices should have responded differentially to the announcement depending on the market's assessment of the likelihood that the lower rate would affect shareholder taxes. Consistent with Amoako-Adu, et. al (1992), Harris and Kemsley (1999), and Collins and Kemsley (1998), this study uses dividend yields to proxy for the valuerelevance of the expected capital gains tax. Investors are assumed to place less (more) valuerelevance on the expected capital gains tax rate when assessing firms with higher (lower) dividend yields. If equity prices reflect expected capital gains taxes, stock returns around the announcement should be negatively correlated with dividend yields. ${ }^{2}$

Consistent with investors discounting share prices for expected capital gains taxes, we find returns are decreasing in dividend yields. During the week of the budget accord, the mean return was 12 percent for non-dividend-paying stocks and 6 percent for dividend-paying stocks. The spread exceeded the difference between the groups for any week from January 1995 to the week in question. No similar price movements were detected in the weeks preceding or following the accord. Results hold after controlling for the normal covariability between dividend-paying and non-dividend-paying firms. Among dividend-paying firms, stock returns are negatively correlated with dividend yields.

The inferences of the paper suggest that none of the current perspectives fully explains the role of shareholder taxes in equity valuation. The results are inconsistent with both the "traditional" view that non-tax benefits offset shareholder taxes and the tax-irrelevance perspective (Miller and Scholes (1978)) that marginal investors are tax-exempt. Instead the

\footnotetext{
${ }^{2}$ The predictions are similar to discussions in the business press around the announcement. An unnamed veteran capital market strategist reportedly stated that the rate reduction "would attract investor attention even more toward stocks with a high probability of capital appreciation and away from dividends." (Wall Street Journal, May 5, 1997, page $\mathrm{C} 12)$.
} 
results suggest that anticipated shareholder taxes affect firm values. However, the findings are inconsistent with the exclusive role of dividends in the new view's tax capitalization perspective. Additional research is needed to assess the generalizability of these results beyond the capital gains tax rate shock provided by the budget accord.

Finally, possible shareholder clientele effects are ignored throughout the paper. One explanation for the findings is that non-dividend-paying (and low-dividend) stocks are held by shareholders that are subject to greater capital gains taxation than shareholders of other companies. Suppose a firm's dividend yield varies with its shareholders' tax status. The marginal investors in non-dividend-paying stocks may be individuals in the maximum personal tax bracket and the marginal investors in other stocks may be pensions, tax-exempt organizations, or foreigners, which are not subject to the capital gains tax rate. If so, cuts in the capital gains tax rate should increase the value of non-dividend-paying stocks more than other stocks.

No tests of the clientele explanation are conducted in this study. Determining whether clientele effects explain the results are beyond the scope of this paper. In particular, we do not test the clientele explanation against an alternative explanation that shareholders are constant across companies and the source of cross-firm variation is the proportion of shareholder profits received in payments subject to the capital gains tax. The findings in this study are consistent with both explanations.

The remainder of the paper is organized as follows: Section 2 reviews the capital gains taxes levied on secondary trades, liquidations, and share repurchases. Section 3 provides background information concerning the budget agreement and the capital gains tax rate reduction. Section 4 presents the empirical tests and results. Concluding remarks follow. 


\section{Capital Gains Taxes}

\subsection{Overview}

Shareholder capital gains taxes are assessed on the difference between a stock's sales price and its investor's tax basis. Changes in expected capital gains tax rates could affect share prices in at least three ways. First, when companies repurchase shares from their shareholders on an ongoing basis or at liquidation, capital gain taxes are levied on the difference between the shareholder's distribution and tax basis. Thus, firm value varies with the dividend payout ratio (i.e., the proportion of value realized in the liquidating event) and the capital gains tax rate. ${ }^{3}$ Second, secondary trading affects firm value because it accelerates capital gains taxes that could have been deferred until the company liquidated. Third, even if all profits are distributed and taxed as dividends (i.e., the liquidating distribution creates zero capital gains), investors who realize their profits in the secondary markets will be taxed at the capital gains rate.

The following example illustrates the potential interplay between dividend policy and capital gains rates in a two-period context. Suppose the firm has a $\$ 10$ investment that earns $\$ 1$ after corporate tax during a year, at the end of which it liquidates. Investors face a 40 percent ordinary income tax rate and a 40 percent capital gains rate.

In this scenario, the dividend payout policy could affect returns in two ways. First, assume that investors buy and hold through liquidation. Then, if the firm has a 100 percent dividend payout ratio, the after-tax cash flow to the investor at the end of the year is $\$ 1 \times$ ( 1 $40 \%)+\$ 10=\$ 10.60$. Assuming a 6 percent after-tax cost of capital, the value of the investment

\footnotetext{
${ }^{3}$ For ease of exposition, references to shares repurchased in a liquidating event include shares repurchased during the life of the company since they receive similar tax treatment.
} 
at the beginning of year is $\$ 10.60 / 1.06=\$ 10$. For this firm, a change in capital gains rates would have no effect on its value unless it affected the attractiveness of alternative investments.

Moreover, if the firm does not pay dividends, $\$ 11$ is distributed at liquidation and the investor still receives $\$ 1 \times(1-40 \%)+\$ 10=\$ 10.60$. Assuming the same cost of capital, the price at the beginning of year 1 remains $\$ 10.60 / 1.06=\$ 10$. However, suppose at the beginning of the year, it is announced that the capital gains tax rate drops immediately to 20 percent. Assuming the cost of capital is unchanged, the price becomes $\$ 10.80 / 1.06=\$ 10.19$, an announcement day return of $\$ 0.19 / \$ 10=1.9 \% .{ }^{4}$ In this case, the announcement day return occurs because the liquidating event will be taxed at the capital gains rate. ${ }^{5}$

However, capital gains treatment for the liquidating distribution is not necessary to achieve the same price response. Consider the following three scenarios. In the first case, earnings are distributed through a $\$ 1$ dividend at the end of year 1 (i.e., all distributions are treated as dividends). As shown above, if there is no trading, the price at the beginning of the period is $\$ 10$. In the second case, suppose immediately following receipt of the dividend, the investor sells the stock. The new investor receives $\$ 10$ and pays no tax. The original investor receives $\$ 10+\$ 0.60=\$ 10.60$ making the original investment worth $\$ 10.60 / 1.06=\$ 10$. Prices are unaffected by capital gains tax rates in either situation.

In the third case, assume the firm pays no dividend prior to liquidation and that the investor sells the share immediately prior to liquidation. The purchaser of the share would be willing to pay $\$ 11$ because he would receive $\$ 11$ in the final distribution and pay no taxes. The

\footnotetext{
${ }^{4}$ In this case, the relatively small return is a consequence of the assumption that the firm only has a one-year life. For a multi-year lived firm, the return would be higher.

${ }^{5}$ The preceding assumes that the discount rate is unaffected by the tax rate change. If the discount rate increases as a consequence of a capital gains rate cut, the reaction for companies with capital gains distributions would be smaller but the price reaction for companies with ordinary income distributions would be negative (rather than zero) so the implication that the firms with capital gains distributions outperform those with ordinary income distributions would remain unchanged.
} 
seller (original investor) would receive $\$ 11$ and pay $\$ 0.40$ in taxes. Consequently, the original investor would be willing to pay $\$ 10$ for the original investment if the capital gains tax rate were 40 percent. If the capital gains rate dropped to 20 percent, the price would increase to $\$ 10.80 / 1.06=\$ 10.19$.

These examples illustrate several facts. First, differential taxes on capital gains and dividends can have valuation implications. Second, those valuation implications can result because dividends are taxed differently from both liquidating distributions and secondary trades. Third, in the face of secondary trading or liquidating distributions, share prices will react positively to the announcement of a capital gains tax reduction if the firm has appreciated in value. Fourth, the magnitude of the stock price reaction to an announced reduction in capital gains tax rates will be decreasing in the dividend payout ratio of the firm. A more general model of secondary trading effects is detailed in the following section.

\subsection{Model of Secondary Trading}

A concurrent study, Collins and Kemsley (1998), extends Ohlson's (1995) residualincome valuation model to incorporate the capital gains taxes from secondary trading into equity prices. We adopt a different modeling approach but reach a similar conclusion. Both papers assume stock prices rise if firms do not immediately distribute all internally generated cash flows to shareholders. This appreciation creates the potential for capital gains in the secondary market.

Suppose a firm has constant free cash flows of $\mathrm{F}$ per period. ${ }^{6}$ If so, firm value at the beginning of the life of the firm can be expressed as the present value of future free cash flows. Firm value can also be expressed as the present value of shareholder distributions (D). For

\footnotetext{
${ }^{6}$ Similar implications would follow if cash flows were assumed to grow over time. One can view our assumption as normalizing cash flow growth to zero.
} 
simplicity, assume a distribution growth rate, $\gamma$, that equates the two expressions for price. This equality can be expressed as:

$$
\sum_{n=1}^{\infty} \frac{F}{(1+r)^{n}}=\sum_{n=1}^{\infty} \frac{D_{1}(1+\gamma)^{n-1}}{(1+r)^{n}}
$$

where $\gamma$ reflects the required change in distributions over the life of the company needed to distribute all corporate cash flows to shareholders.

Rearranging terms, we find that distribution growth rate is a function of the distribution payout ratio (i.e., the dividend payout ratio if all distributions are taxed as dividends):

$$
\gamma=r\left(\frac{F-D_{1}}{F}\right)
$$

The share price at time $t\left(\mathrm{P}_{\mathrm{t}}\right)$ equals the expected dividends at $\mathrm{t}+1$, after shareholder dividend taxes $\left(\tau^{\mathrm{d}}\right)$, plus the anticipated sales price at $t+1\left(\mathrm{P}_{t+1}\right)$ less shareholder capital gains taxes $\left(\tau^{c}\right)$ on the change in price, discounted at $r$ :

$$
P_{t}=\mathrm{E}_{t}\left[\frac{P_{t+1}+D_{t+1}\left(1-\tau_{t+1}^{d}\right)-\left(P_{t+1}-P_{t}\right) \tau_{t+1}^{c}}{1+r}\right]
$$

The share price at $t+n$ is a function of the share price at $t+n+1$ for all $n$. Thus, current prices $\left(\mathrm{P}_{0}\right)$ can be expressed as:

$$
P_{0}=\sum_{n=1}^{\infty} \frac{D_{1}(1+\gamma)^{n-1}\left(1-\tau_{n}^{d}\right) \prod_{m=1}^{n-1}\left(1-\tau_{m}^{c}\right)}{\prod_{m=1}^{n}\left(1+r-\tau_{m}^{c}\right)}
$$

If $\tau_{t}^{c}=\tau^{c}$ and $\tau_{t}^{d}=\tau^{d}$ for all $\mathrm{t}$, then equation (4) simplifies to:

$$
P_{0}=\Gamma^{\infty} D_{1}(1+\gamma)^{n-1}\left(1-\tau^{d} d\right)\left(1-\tau^{c}\right)^{n-1}
$$




$$
P_{0}=\frac{D_{1}\left(1-\tau^{d}\right)}{r-\gamma\left(1-\tau^{c}\right)}
$$

Substituting equation (2) into equation (6) and rearranging terms:

$$
\begin{aligned}
& P_{0}=\left[\frac{D_{1}\left(1-\tau^{d}\right)}{r}\right]\left[\frac{1}{1-\left(\frac{F-D_{1}}{F}\right)\left(1-\tau^{c}\right)}\right] \\
& \frac{\partial P_{0}}{\partial \tau^{c}}=-\left[\frac{D_{1}\left(1-\tau^{d}\right)}{r}\right]\left[\frac{F-D_{1}}{F}\right]\left[\frac{1}{1-\left(\frac{F-D_{1}}{F}\right)\left(1-\tau^{c}\right)}\right]^{2} \\
& \frac{\partial P_{0}}{\partial \tau^{c}}=-P_{0}\left(\frac{F-D_{1}}{\left(F-D_{1}\right) \tau^{c}+D_{1}}\right)
\end{aligned}
$$

The derivative in equation (9) is negative when $F>D_{1}$. In other words, if firms retain part of their cash flow, a decrease in the capital gains tax rate increases their stock prices and the extent of the price increases varies with their dividend payouts. If all cash flows are distributed as dividends (i.e., $\mathrm{F}=\mathrm{D}_{1}$ ), then no profits are retained, the stock price remains constant, and the derivative equals zero. If distributions exceed cash flows $\left(F<D_{1}\right)$, then shareholders are facing capital losses if they sell and a reduction in the rate lowers the value of the loss (assuming capital losses offset capital gains). Consequently, the derivative is positive.

To gauge the economic magnitude of the 1997 capital gains tax cut, assume a firm is generating $\$ 25$ of $\mathrm{F}$ and paying $\$ 5$ of $\mathrm{D}$. Using the tax rates before the reduction ( $\tau^{\mathrm{d}}=0.4$, $\left.\tau^{\mathrm{c}}=0.28\right)$ and a discount rate of 10 percent, equation 7 provides a share price of $\$ 47$. Therefore, the 1997 capital gains tax rate cut from 28 percent to 20 percent should have increased the price of this company by approximately $\$ 7$ (the derivative of 89 times 0.08 ) or 15 percent. 


\subsection{Share Repurchases and Liquidating Dividends}

Besides the capital gains taxes arising in secondary trading, capital gains taxes also are levied when companies repurchase their stock and when they liquidate. Unlike secondary trades, share repurchases reduce (and liquidating distributions eliminate) the potential for future dividend taxes.

All corporate profits (net of losses) eventually are included in taxable shareholders' income and taxed at either the dividend tax rate or the capital gains tax rate. ${ }^{7}$ The dividend tax rate applies to distributions from accumulated or current "earnings and profits" (E\&P), which is taxable income adjusted to approximate economic income. Dividends are taxed in the year received at the ordinary income tax rate. Shareholder taxes on earnings not paid out in dividends are deferred until distributed.

Eventual dividend taxation is unaltered by secondary trading. Purchasers of shares in the secondary market acquire the company with its prior owners' E\&P (and thus potential dividend taxation) intact. Although the secondary market for equity creates capital gains and losses for sellers, it leaves corporate E\&P undisturbed for determining future dividend taxes.

If companies avoid share repurchases and distribute nothing at liquidation, all net earnings are eventually paid out in dividends, and taxation at ordinary rates is inevitable. This is the foundation of public finance's "new" view of tax capitalization. This view asserts investors bid down the price of equity to reflect the dividend taxes payable upon distribution of E\&P (e.g., Auerbach (1979), Bradford (1981), and King (1977)). All distributions are assumed to face

\footnotetext{
${ }^{7}$ Three primary shareholder exceptions to this general rule are: (1) qualified pension plans whose beneficiaries are taxed at the ordinary tax rate on all distributions, (2) tax-exempt organizations, such as universities and churches, which avoid all taxes on investments, and (3) many foreign investors whose returns are governed by treaty provisions and foreign tax laws and are not be subject to U.S. tax law.
} 
dividend taxation. Consequently, the potential for share repurchases and liquidations to reduce $\mathrm{E} \& \mathrm{P}$, and thus avoid dividend taxes, is ignored.

Earnings, however, need not eventually be paid out in dividends. In fact, the mean dividend payout for U.S. companies is less than 20 percent of current earnings with the median company paying no dividends. Instead, firms can distribute corporate profits and reduce E\&P without shareholders facing dividend taxes. For example, companies can buy their own stock. If the purchase is not pro-rata, the redemption reduces E\&P, and shareholders are taxed on the difference between the proceeds and their tax basis (cost) in the stock at the capital gains tax rate. ${ }^{8}$ Liquidations following taxable asset acquisitions or special elections following stock acquisitions also eliminate E\&P.

The extent to which these opportunities for converting distributions from dividend taxes to capital gains taxes affect firm values is an empirical question. However, if the market expects earnings ultimately to receive capital gains treatment, valuation should be decreasing in capital gains tax rates. The appendix reviews the extant empirical literature to assess the frequency that firms utilize share repurchases, liquidations following taxable asset acquisitions, and special elections following stock acquisitions.

\subsection{An Alternative Perspective}

Contrary to the preceding predictions, numerous articles in the business press around the budget accord asserted that the capital gains tax reduction would lower stock prices in the short

\footnotetext{
${ }^{8}$ The buyback reduces E\&P by the ratable portion of the company redeemed. For example, if a firm's E\&P are $\$ 10$, redeeming 30 percent of its stock reduces $\mathrm{E} \& \mathrm{P}$ by $\$ 3$. If shares are acquired at a discount to their tax book value (E\&P plus contributed and paid-in capital), less E\&P are extinguished. For example, assume the company's E\&P are $\$ 10$ and other capital is $\$ 6$. If 30 percent of the company is redeemed for $\$ 2$, E\&P are reduced by only $\$ 1.25$ $[(10 / 10+6) * 2)$.
} 
run because shareholders would respond to the rate reduction by selling appreciated properties. For example, the Wall Street Journal (May 5, 1997, page C1) reported “. . ., a burst of selling may hit the markets, strategies say. That could be the reaction, at least temporarily, as investors with big long-term profits rush to lock in their gains." Earlier in the year, the Wall Street Journal (February 19, 1997, page A1) reported that policymakers were advocating a January 1 effective date for any capital gains tax rate reductions "to avoid possible market disruptions that might come from investors delaying transactions in anticipation of a future effective date."

Under certain circumstances, stock prices can be shown to be increasing in capital gains tax rates if capital gains taxes are viewed as transaction costs for which sellers demand compensation from buyers. A cut in the capital gains tax rate reduces the required compensation, lowering the costs of acquiring shares and thus lowers stock prices.

For example, suppose a shareholder has a reservation price $\mathrm{R}$, at which he is indifferent between holding and selling the stock and which is unaffected by the change in capital gains rates. ${ }^{9}$ Assume the shareholder is subject to a capital gains tax rate of $g$ and has a tax basis in the property of C. To sell, the shareholder will demand a price no less than $\mathrm{P}$, where:

$$
P=\frac{R-C g}{1-g}
$$

At any price less than $\mathrm{P}$, the shareholder will refuse to sell, hold the stock, avoid the capital gains tax, and collect dividends. Under this model, it is simple to show that stock prices are increasing in capital gains tax rates:

$$
\frac{\partial P}{\partial g}=\frac{R-C}{(1-g)^{2}}
$$

\footnotetext{
${ }^{9}$ Such a reservation price might exist, for example, because the holders' alternative to selling is to hold the stock and collect dividends in perpetuity at ordinary income rates. To the extent the alternative is to hold the stock for a more limited time and collect dividends, then sell and pay tax at the new capital gains tax rate, the effect would be mitigated.
} 
If the reservation price exceeds the share's tax basis, the derivative is positive, indicating that a decrease in the capital gains tax rate will reduce the price that the shareholder will demand to sell his stock, potentially resulting in a price decline.

We are unaware of any study that provides evidence directly supporting this characterization of stock prices and capital gains tax rates. However, Landsman and Shackelford (1995) provide similar evidence in their examination of RJR Nabisco's stock price during its 1989 leveraged buyout. They find a negative correlation between the price of RJR Nabisco's stock and the average tax basis of the shares sold during the 76 trading days from initiation to completion of its buyout. In other words, shareholders facing larger capital gains taxes demanded higher prices during the buyout than shareholders facing smaller capital gains taxes. A logical conclusion from their study is the compensation to cover the capital gains taxes would have been less if the capital gains tax rate had been reduced. Whether their findings in a tender offer generalize to other settings is unclear. The evidence, presented later in this paper, is inconsistent with this view in that non-dividend stocks (which are likely to produce higher capital gains on sale) react positively to the capital gains rate drop.

\section{Development of the Budget Agreement's Capital Gains Tax Rate Reduction}

President Clinton was reelected in 1996 without endorsing a capital gains tax rate cut, and his 1998 budget, introduced in March 1997, did not propose to reduce the capital gains tax rate. However, commentators speculated that the President might accept a capital gains tax rate reduction in 1997 in exchange for Republican concessions on other issues. In March 1997, Speaker Newt Gingrich and Senate Majority Leader Trent Lott dampened expectations of a capital gains tax rate cut, stating that a balanced budget must take precedent over any tax cuts. 
Although Gingrich softened his statements following an outcry by conservative Republicans, it remained uncertain whether a balanced budget was feasible, not to mention a capital gains tax rate reduction. On March 19, House Ways and Means Committee Chair William Archer said that if a tax bill were enacted in 1997, "there is no greater than a 50-50 chance" it would include reductions in the capital gains tax rate (Tax Notes, March 24, 1997).

In April 1997, the Administration and the Republican leadership released little public information about the ongoing, private budget negotiations. On April 30 the Congressional Budget Office reduced its estimate of the 1997 deficit by $\$ 45$ billion and stated that annual revisions of "similar amounts" were appropriate for years 1998-2002. The CBO's announcement was a major surprise because no revision was scheduled until August.

The next day the Wall Street Journal and New York Times announced that a budget agreement was imminent. Both newspapers speculated that the CBO's new projections had enabled the President and Congress to balance the budget without forgoing desired expenditure programs and tax cuts. ${ }^{10}$ The following day, May 2, the President and Congressional leaders announced an agreement to balance the budget by 2002 and, among other things, reduce the capital gains tax rate. At the announcement OMB Director Raines admitted that the revision had enabled the negotiators to "make some adjustments." He stated that the revision had provided an additional tax revenue, enabling a balanced budget in 2002. On May 7, Senate Finance Chairman William Roth and House Ways and Mean Chairman William Archer jointly announced that the effective date for any capital gains tax cut would be May 7 .

\footnotetext{
${ }^{10}$ In reviewing the factors that ended "a two-year budget stalemate begun with the House Contract with America," Tax Notes (May 5, 1997, p. 607) concluded, "In the end, negotiations may have been helped most by news from congressional analysts of an unexpected windfall of approximately $\$ 200$ billion from a stronger economy over the next five years than earlier predicted."
} 
The capital gains tax rate was not specified in the agreement, but the business press immediately began to speculate that maximum rates between 15 percent and 20 percent were likely, down from the current rate of 28 percent. After three months of haggling over details, the general features of the May budget agreement were codified in the Taxpayer Relief Act of 1997 (TRA 97). ${ }^{11}$ Among other changes, it lowered the individual maximum long-term capital gains tax rate to 20 percent.

The sudden budget agreement following the CBO's unexpected revisions potentially provides an unusually powerful setting for assessing the value relevance of U.S. taxes. Typically U.S. tax legislation is constructed over long periods--many months or even years. Information leaks during policy deliberations impede identification of an event period and thwart successful use of conventional event study methodology. This study's research design assumes that the information about future capital gains tax rates was dispersed to market participants in a sufficiently brief period that conventional capital market methodologies can detect the effect of capital gains taxes on firm values.

Generally, such methodologies have been relegated to tax changes in parliamentary governments (e.g., Amoako-Adu, et al. (1992)) where tax and budget information is strictly confidential and information links can result in removal of top government officials. ${ }^{12}$ One exception is Cutler (1988), who tests for a market response to each house's passage of the Tax Reform Act of 1986. Failing to detect a large market response, he concludes, “These results

\footnotetext{
${ }^{11}$ Confirming general enactment of the budget agreement, Tax Notes (July 28, 1997, p.445) commented in the latter days of negotiation that "They'll disagree on this and on that, but in the end, they'll make a deal. And it will basically be the same deal the President and Republican leaders agreed to back in May."

${ }^{12}$ Tillinger and Loudder (1994) demonstrate the difficulty of using event studies to evaluate tax legislation. They report that abnormal stock returns of companies not paying dividends exceeded abnormal returns of companies paying dividends in 1992 and 1993. They link this two-year (the event period) differential to 1993 legislation that increased the tax rate applied to dividends without changing the capital gains tax rate. Although the conclusion is consistent with the finding in this paper, the length of the event period impedes their ability to rule out alternative explanations.
} 
leave unanswered questions about what the tax news meant to the market, and whether the news was efficiently incorporated in stock prices (p. 1108)."

One possible explanation for Culter (1988)'s weak results is that it may have taken time for investors to price the complex revisions in 1986 tax reform. ${ }^{13}$ If so, our study may find a stronger price response to taxes because the valuation implications of the relatively simple 1997 capital gains tax rate cut should have been more quickly impounded into price. $^{14}$

\section{Empirical Analysis}

\subsection{Research Design}

The empirical analysis is based on the observation that, if expected capital gains tax rates affect valuation, then stock prices should increase for firms on the announcement of the budget agreement, and particularly so for firms that pay less in dividends. The basic regression is:

$$
\text { Return }=\alpha+\beta_{1} \text { Dividend Variable }+\beta_{2} \text { Control Variables }+\varepsilon
$$

The return is computed over the five-day period, Tuesday, April 29, 1997 through Monday, May 5, 1997, during which most of the uncertainty surrounding the budget agreement was resolved. One advantage of the budget agreement for this analysis is that few specific provisions in the agreement (other than the capital gains change) clearly benefit one group of firms over another and, hence, potentially confound the analysis. Nevertheless, a series of control variables is added to mitigate the possibility that omitted correlated variables spuriously affect the study's inferences.

\footnotetext{
${ }^{13}$ Consistent with this explanation, Plumlee (1997) shows that the complexity of the 1986 Act impeded financial analysts' forecast accuracy.

${ }^{14}$ Besides the cut in the capital gains tax rate, the only major tax changes in the accord were a child tax credit, estate tax relief, and education tax incentives. Expanded IRAs were included in the final bill.
} 
The dividend variable captures the presence of (or extent of) dividend payments. To the extent the change in expected capital gains tax rates affects valuation, the effect should be most pronounced for firms that are less likely to pay dividends, all else equal. Thus, $\beta_{1}$ is the coefficient of primary interest and is expected to be negative.

The analysis is based on the 2,000 largest U.S. corporations as reported by Datastream. Of the 1,975 sample firms with complete data, 728 (37 percent) pay dividends. For those firms, the mean dividend yield is 2.8 percent. Table 1 presents additional descriptive statistics.

\subsection{Dividend Status Regressions}

The initial regression investigates the stock price change of dividend-paying and nondividend-paying stocks, as follows:

$$
\text { Return }=\alpha+\beta_{1} \text { Dividend Dummy }+\varepsilon
$$

Because dividend initiations and omissions are rare, past dividend status is assumed to predict future status and, hence, the impact of capital gains tax rate changes on investors.

The simple regression results in Table 2, Column A suggest dividend status is an important explanatory variable for stock price reactions to the budget accord. As predicted, the coefficient on the dividend variable is negative (-6.24 with a $t$-statistic of -17.1$)$, indicating nondividend-paying companies outperformed dividend-paying companies during the event week.

The mean return over the week in question is 6 percent for dividend-paying stocks and 12 percent for the non-dividend-paying firms. The return differential is consistent with the capital gains tax reduction being particularly good news for non-dividend-paying stocks. ${ }^{15}$

\footnotetext{
${ }^{15}$ Specification tests, detailed below, confirm this conclusion. Results are robust to inclusion of a variety of control variables including industry, leverage, prior stock performance, and beta.
} 
To assess the uniqueness of this week's differential stock response, equation (13) was reestimated for every week between January 1995 and the event week. Of those 129 weeks, the coefficient on the dummy variable in the event week was the largest in absolute terms, suggesting that, whatever occurred during the week was highly unusual. However, one potential remaining concern is that non-dividend-paying stocks always react more strongly to factors that move the market. If so, the large difference between dividend and non-dividend-paying stocks may be solely attributable to the increase in stock prices during the week of the accord.

To control for the normal covariability between dividend and non-dividend stocks, we estimate a regression of each firm's weekly return for the 129 weeks from January 1995 through the event week (239,296 observations) on two variables: (a) the average return for dividendpaying stocks during the week and (b) a categorical variable for non-dividend-paying stocks in the event week. Inclusion of the average return for dividend-paying stocks should control for normal covariability. The categorical variable should capture any "abnormal" returns to nondividend stocks relative to dividend stocks during the event week.

The coefficient on the categorical variable is 5.79 , indicating that non-dividend stocks outperformed dividend stocks after controlling for the normal covariability between dividend and non-dividend stocks. The coefficient estimate is only slightly less than the 6.24 coefficient in Table 2, Panel A, and remains statistically significant. Results are qualitatively insensitive to alternative specifications of the abnormal returns model.

The positive market return for both dividend-paying firms and non-dividend-paying firms during the week is consistent with the budget agreement being good news for the market as a whole. During the week, the Dow Jones Industrial Average rose 6 percent and the Nasdaq 
Composite rose 10 percent. ${ }^{16}$ However, readers should be cautious to infer that the tax cut increased stock prices because the budget accord occurred in the early stages of a surge in stock prices. Specifically, the Dow Jones Industrial Average climbed from under 6400 in mid-April to over 8200 in early August. Nevertheless, the week in question did account for 58 percent of the Dow's increase and 67 percent of the rise in the Nasdaq Composite in April and May. In addition, the Dow Jones Industrial Average and the Nasdaq Composite were largely unchanged in the week preceding and the week following the agreement. The DJIA rose 2 (1) percent in the week preceding (following) the accord week. The Nasdaq rose $1(0)$ percent in the week preceding (following) the accord week. Moreover, a casual review of the business press during that week reveals no particularly newsworthy events, other than the accord. Thus, the evidence suggests that investors viewed the budget agreement as favorable regardless of dividend status.

At a minimum, the sharp rise in share prices following the accord overwhelmed any possible sell-off of appreciated securities. Recall that the business press widely reported that the capital gains tax rate cut would unleash selling pressure that would drive down the prices of stocks that had already appreciated. In addition, this paper provides no evidence supporting a reduction in transaction costs, arising from sellers demanding less compensation for capital gains taxes following the rate reduction. The results imply that any downward price movement caused by sell-offs or by reduced transaction costs was more than offset by upward price pressures. Specifically, the DJIA increased on May 7, the effective date for the lower rates, and during the

\footnotetext{
${ }^{16}$ In the spirit of this paper, the Wall Street Journal (April 25, 1997) reported that Brian Wesbury, chief economist at the Chicago bond firm of Griffin, Kubik, Stephens \& Thompson, was characterizing the Nasdaq Composite as an indicator of the market's expectations of the future capital gains tax rate, "a little cap-gains futures contract." Wesbury had related movements in the Nasdaq since November 1996 to changes in the probability of a capital gains tax rate reduction. The DJIA was termed less sensitive to capital gains tax changes because its stocks "throw off a relatively heavy share of their profits in dividends."
} 
week beginning with May 7. By the end of the month, the DJIA (Nasdaq) had risen 1.6 (4.8) percent since May 6.

Rough approximations using the regression coefficient estimates provide some confidence that coefficients are reasonable. The coefficient on the dividend status variable can be used to estimate the market's expectation of the eventual capital gains tax rate reduction. Let $\lambda_{\mathrm{d}}$ equal the percentage of a dividend-paying stock's value expected to be taxed as dividends, and $\lambda_{n}$ equal the percentage of non-dividend-paying stock's value expected to be taxed as dividends. Let $\Delta_{\mathrm{o}}$ equal the change in expected ordinary income tax rates, and $\Delta_{\mathrm{c}}$ equal the change in the expected capital gains tax rate. The reduction in firm value for dividend-paying firms, relative to non-dividend-paying firms can be represented as: $\left(\lambda_{d}-\lambda_{n}\right)\left(\Delta_{o}-\Delta_{c} \Delta \alpha\right)$, where $\Delta \alpha$ is the change in the likelihood of a capital gains tax rate cut.

Assume the budget agreement did not affect expectations about future ordinary income tax rates $\left(\Delta_{\mathrm{o}}=0\right)$ and that the profits of the dividend-paying firms are taxed as dividends $\left(\lambda_{\mathrm{d}}=1\right)$ and the profits of the non-dividend-paying firms are taxed as capital gains $\left(\lambda_{n}=0\right)$. Also assume that the budget agreement shifted expectations about the capital gains tax cut from impossible to certain $(\Delta \alpha=1)$. Using these parameters, the regression coefficient implies that at the time of the accord, the market anticipated future capital gains tax rates would fall by 6.24 percentage points. With a capital gains tax rate of 28 percent when the agreement was reached, the coefficient suggests that the anticipated future capital gains tax rate was approximately 22 percent. If some profits of dividend firms are expected to face capital gains taxation, the regression coefficient implies a lower future capital gains tax rate. For example, if $\lambda_{\mathrm{d}}$ is 0.5 , the implied future capital gains tax rate is about 16 percent. These simple estimates seem reasonable. Recall immediate speculation in the business press following the accord indicated an 
eventual capital gains tax rate between 15 and 20 percent. TRA 97 reduced the capital gains rate to 20 percent.

An alternative approach is to assume the budget agreement only shifted expectations about passage of the bill. That is, the market anticipated a 20 percent capital gains tax rate $\left(\Delta_{\mathrm{c}}=\right.$ 8) if legislation passed. Solving for $\Delta \alpha$, the regression coefficient of -6.24 suggests that agreement increased the probability of a tax cut by 78 percent.

\subsection{Control Variables}

While suggestive, the average returns in the simple regression do not control for the possibility that other factors may have caused these differences in returns. To ensure that other factors are not driving the results, the regression is modified to include several control variables. The choice of control variables is somewhat ad hoc because theory is insufficiently rich to proscribe other effects of the tax rate change. The controls are:

$\begin{array}{ll}\text { Size } & =\log \text { of market value as of April 28, 1997; } \\ \text { Debt/Assets } & =\text { total liabilities divided by total assets at year-end 1996; } \\ \text { Return on Assets } & =1996 \text { net income divided by year-end total assets; } \\ \text { Book/Market Ratio } & =\text { book value divided by market value of equity at year-end } 1996 .\end{array}$

Size is designed to ensure that the results are not caused by smaller, non-dividend-paying firms outperforming larger, dividend-paying firms. Debt/Assets is included to control for differences in leverage across firms. ${ }^{17}$ Return on assets is designed to capture differences in profitability across firms. ${ }^{18}$ Book/Market ratio is included to control for differences in

\footnotetext{
${ }^{17}$ Results are consistent if debt is divided by market or book value of equity or if leverage is measured as interest expense divided by market value.

${ }^{18}$ Results are qualitatively unaltered if net income is deflated by total assets or book value of equity.
} 
unrecognized assets, growth prospects and risk across firms. ${ }^{19}$ All control variables are collected from Compustat. ${ }^{20}$ To avoid extreme observations, values of Debt/Assets, Return on Assets and Book/Market are trimmed at the $1^{\text {st }}$ and $99^{\text {th }}$ percentiles. Inferences are insensitive to this trimming.

Table 1 presents descriptive statistics for the control variables, split between dividendpaying and non-dividend-paying stocks. Not surprisingly, dividend-paying stocks are larger, on average, more highly levered (median debt/asset ratios of 0.42 versus 0.64 ), more profitable (median ROA of 13.76 percent versus 10.8 percent respectively), and have higher book/market ratios $(0.33$ versus 0.18$)$ implying lower expected earnings growth. $t$-tests of the mean control variables for the two groups are significantly different at conventional levels; however, for each control variable, the two distributions overlap substantially.

Table 2, Column B, shows results including the control variables. Two facts are noteworthy. First, although the coefficient estimate on the dividend indicator variable drops from -6.24 to -5.72 , it remains strongly negative suggesting that differences in returns are not driven primarily by the control variables. Second, only debt/assets and book/market are significantly related to returns (both negatively).

To our knowledge, the impact of the budget agreement and its capital gains tax rate cut should not have varied substantially across industrial sectors. However, to ensure that the results are not caused by differences across industries, Table 2, Column $\mathrm{C}$ reports results using industry indicator variables. Specifically, firms are split into financial, extractive, manufacturing, utilities

\footnotetext{
${ }^{19}$ Book/Market is employed rather than the inverse to avoid extreme values for firms with book values of equity close to zero, however, inferences are insensitive to this choice.

${ }^{20}$ The number of observations drops slightly for the regressions including the control variables because Compustat data are unavailable for every sample firm.
} 
and services sectors based on their Datastream level 3 industry codes. Again, inferences are unaffected. Only the indicator variable for the extractive industries is statistically significant.

To determine whether the results are robust across industries, the simple regression was reestimated for each industry separately. The relation between stock returns and the dividend indicator variable is significantly negative in each industry, except the extractive industry where it is insignificant. To ensure that results are not driven by the coarseness of the industry partition, firms are split into finer partitions, up to Datastream level 6 industry codes that divide firms into eighty-three groupings. Results are always consistent.

Finally, unreported regressions show that inferences are unaltered when the explanatory variables include beta or the percentage change in stock prices over various combinations of the months preceding the event period. In addition, excluding firms that went ex-dividend during the examination period does not qualitatively affect the results.

\subsection{Dividend Yield Regressions}

Table 3, Column A, shows results for the following regression estimated only for dividend-paying stocks:

$$
\text { Return }=\alpha+\beta_{1} \text { Dividend Yield }+\varepsilon
$$

The regression coefficient on the dividend yield is significantly negative, indicating that current dividend yields are correlated with stock price performance during the budget reconciliation week. $^{21}$ The coefficient estimate is -0.51 , indicating that a 1 percentage point

\footnotetext{
${ }^{21}$ Tests in the preceding section assume current dividend-paying status predicts future dividend-paying status. Likewise, tests in this section assume current dividend yields are correlated with future yields. Payouts are imperfect measures, however, to the extent dividend yields vary with past performance and past market movements. For example, because dividend changes lag returns, low dividend yield firms are more likely to have experienced recent stock appreciation.
} 
decrease in the dividend payout ratio results in approximately a one-half percentage point larger stock price increase on the announcement of the budget agreement.

Conclusions are unaffected by inclusion of the control variables from Columns B and C of Table 2. Table 3, Column B shows the coefficient on dividend yield drops slightly is -0.42 , but remains statistically negative. Only market value is also statistically significant. Table 3, Column C, reports results including industry indicator variables. The coefficient estimate on dividend yield is -0.45 . None of the industry indicators is statistically significant. Moreover, when equation (14) is estimated separately for each industry, the coefficient on dividend yield is always significantly negative, except utilities where it is marginally significantly negative and consumer goods where it is negative but insignificant.

A simple model of discounted cash flows suggests that the regression coefficient estimates are reasonable, i.e., consistent with the market correctly anticipating the magnitude of the capital gains tax cut. Assuming all corporate earnings (E) are distributed annually as either dividends (D), subject to the ordinary income tax rate $\left(t_{d}\right)$, or as redemptions, subject to the capital gains tax rate $\left(\mathrm{t}_{\mathrm{g}}\right)$, share prices $(\mathrm{P})$ can be expressed as:

$$
P=r^{-1}\left[D\left(1-t_{d}\right)+(E-D)\left(1-t_{g}\right)\right]
$$

where $r$ is the discount rate (after corporate and shareholder taxes). First differencing equation (15) and assuming that a change in capital gains tax rates does not affect $\mathrm{D}, \mathrm{E}, \mathrm{t}_{\mathrm{d}}$, or $\mathrm{r}$, we find:

$$
\frac{\partial \Delta P}{\partial D}=\frac{t_{g 2}-t_{g 1}}{r}
$$

Let the derivative equal the regression coefficient of -0.51 (from Column A), $\mathrm{t}_{\mathrm{g} 1}$ equal 0.28 (the prior capital gains tax rate) and $\mathrm{t}_{\mathrm{g} 2}$ equal 0.20 (the current capital gains tax rate). Using these parameters, the equation holds with a discount rate of 16 percent, which does not seem unreasonable. Alternatively, assuming a smaller discount rate of 10 percent, the regression 
coefficient implies that capital markets differentiated among dividend-paying stocks around the budget agreement as if they anticipated a future capital gains tax rate of 23 percent.

To investigate further the relation between dividends and the reaction to the budget agreement, dividend-paying stocks are split into quartiles based on dividend yields, where:

DUM1 $=1$ if dividend yield is greater than zero but below 1.18 percent,

DUM2 $=1$ if dividend yield is between 1.18 percent and 2.07 percent,

DUM3 $=1$ if dividend yield is between 2.07 percent and 3.40 percent, and

DUM4 = 1 if dividend yield is greater than 3.40 percent.

Table 4 shows a monotonic relation between dividend yields and the weekly stock return. Column A indicates that, relative to the quartile with the lowest dividend yield, the $2^{\text {nd }}, 3^{\text {rd }}$ and $4^{\text {th }}$ quartiles had returns that were lower by 1.77 percentage points, 2.13 percentage points and 3.30 percentage points, respectively. Again, inclusion of control variables (Column B) and industry indicator variables (Column C) do not affect the inferences.

\section{Conclusions}

Prior studies generally have ignored the effect of anticipated shareholder taxes on firm values or limited the focus to dividend taxes. This paper presents evidence consistent with capital gains taxes significantly affecting share prices during a week when expected capital gains tax rates likely were revised downward. Regression summary statistics show that stock prices moved inversely with dividend yields when the 1997 budget reconciliation was reached. The share prices of firms not currently paying dividends increased approximately 6 percentage points more over a five-day window than the share prices of other firms. Among firms paying dividends, the change in share prices was decreasing in dividend yields. Results are robust to a 
battery of sensitivity checks, mitigating concerns that inferences are affected by omitted factors that are correlated with dividend yields.

The results are consistent with at least two related explanations. First, to the extent a stock's returns are expected to be taxed as capital gains, a reduction in the expected capital gains tax rate enhances the attractiveness of the investment to investors. Second, to the extent a firm's stock is held by shareholders subject to the capital gains tax, a reduction in the expected capital gains tax rate increases its market value. The findings present evidence consistent with neither a sell-off of appreciated securities following the rate reduction nor a reduction in the compensation for capital gains taxes that selling shareholders demand from buyers. The upward price pressure around the accord dominated any downward price pressure imposed by these factors.

These findings do not fit nicely with any of the current models relating equity valuations and shareholder taxes. Unlike the traditional and tax-irrelevance views, the findings are consistent with capitalization of shareholder taxes. However, unlike the new view, the results suggest capitalization of shareholder taxes extends beyond dividend taxes to include capital gains taxes. Because dividend yields are zero for many companies and approach zero for others, tax capitalization of expected capital gains taxes may be an important, previously overlooked, component of equity pricing. 


\section{References}

Amoako-Adu, B., Rashid, M., Stebbins, M., 1992. Capital gains tax and equity values: Empirical test of stock price reaction to the introduction and reduction of capital gains tax exemption. Journal of Banking and Finance 16: 275-287.

Auerbach, A., 1979. Wealth maximization and the cost of capital. Quarterly Journal of Economics 93: 433-446.

Auerbach, A., Hassett, K., 1997. On the marginal source of investment funds. University of California, Berkeley working paper.

Auerbach, A., Reishus D., 1988. The impact of taxation on mergers and acquisitions. In Auerbach, A. (Ed.), Mergers and Acquisitions. University of Chicago Press, Chicago, pp.157-183.

Bagwell, L., Shoven J., 1989. Cash distribution to shareholders. Journal of Economic Perspectives 3: 129-140.

Bradford, D., 1981. The incidence and allocation effects of a tax on corporate distributions. Journal of Public Economics 15: 1-22.

Collins, J., Kemsley D., 1998, Capital gains and dividend taxes in firm valuation and corporate financial policy. University of North Carolina and Columbia University working paper.

Cutler, D., 1988. Tax reform and the stock market: An asset price approach. American Economic Review 78: 1107-1117.

Erickson, M., 1998. The effect of taxes on the structure of corporate acquisitions. Journal of Accounting Research 36: 279-298.

King, M., 1977. Public Policy and the Corporation, London: Chapman and Hall.

Harris, T., Kemsley D., 1999. Dividend taxation in firm valuation: New evidence. Journal of Accounting Research, forthcoming.

Hayn, C., 1989. Tax attributes as determinants of shareholder gains in corporate acquisitions. Journal of Financial Economics 23: 121-153.

Landsman, W., Shackelford D., 1995, The lock-in effect of capital gains taxes: Evidence from the RJR Nabisco leveraged buyout, National Tax Journal 48: 245-259.

Miller, M., Scholes M., 1978. Dividends and taxes. Journal of Financial Economics 6: 333-364. 
Ohlson, J., 1995. Earnings, book value and dividends in security valuation. Contemporary Accounting Research, 661-688.

Plumlee, M., 1997. The impact of tax complexity on analysts' effective tax rate forecasts. University of Michigan unpublished dissertation.

Schipper, K., Smith A., 1991. Effects of management buyouts on corporate interest and depreciation tax deductions. Journal of Law and Economics, 295-341.

Tillinger, J., Loudder M., 1994, Evidence of taxpayer behavioral responses to higher tax rates. Tax Notes (October 17), 361-369. 


\section{TABLE 1}

\section{Descriptive Statistics}

$\underline{\text { Mean }}$

$\underline{25^{\text {th }} \mathrm{Per}}$.

$\underline{\text { Med. }}$

$\underline{75^{\text {th }} \text { Per. }}$

\section{Non-Dividend Stocks}

$\begin{array}{lcccc}\text { Return (percent) } & 12.2 & 4.6 & 10.7 & 18.7 \\ \log (\mathrm{MV}) & 6.76 & 6.12 & 6.55 & 7.25 \\ \text { Debt/Assets } & 0.45 & 0.24 & 0.42 & 0.61 \\ \text { Return on Assets } & 6.62 & 3.36 & 10.80 & 17.45 \\ \text { Book/Market } & 0.23 & 0.06 & 0.18 & 0.35\end{array}$

\section{Dividend Stocks}

$\begin{array}{lcccc}\text { Return (percent) } & 6.0 & 3.2 & 5.5 & 8.1 \\ \text { Log(MV) } & 7.49 & 6.51 & 7.28 & 8.22 \\ \text { Debt/Assets } & 0.63 & 0.50 & 0.64 & 0.78 \\ \text { Return on Assets } & 14.13 & 9.93 & 13.76 & 18.47 \\ \text { Book/Market } & 0.37 & 0.18 & 0.33 & 0.52 \\ \text { Dividend Yield (percent) } & 2.8 & 1.2 & 2.1 & 3.4\end{array}$

Returns are computed over the 5 days, 4/29/97-5/5/97. $\log (\mathrm{MV})$ is the log of market value as of 4/28/97. Debt/Assets is total long-term debt divided by total assets. Return on assets is net income divided by total assets. Book/Market is the book value of equity divided by the market value of equity as of 4/28/97. Dividend Yield is the most recent quarterly dividend, annualized and divided by market value on 4/28/97. 


\section{TABLE 2}

\section{Regression Coefficient Estimates (t-statistics) for All Sample Firms with Dividend Indicator Variable}

\begin{tabular}{|c|c|c|c|}
\hline Intercept & $\begin{array}{r}{ }^{\underline{\boldsymbol{A}}} \\
(42.0)\end{array}$ & $\begin{array}{r}\underline{\boldsymbol{B}} \\
14.13 \\
(10.2)\end{array}$ & $\begin{array}{c}\underline{\boldsymbol{C}} \\
16.07 \\
(10.5)\end{array}$ \\
\hline Dividend Indicator & $\begin{array}{r}-6.24 \\
(-17.1)\end{array}$ & $\begin{array}{r}-5.72 \\
(-11.4)\end{array}$ & $\begin{array}{r}-5.62 \\
(-11.1)\end{array}$ \\
\hline $\log (M V)$ & & $\begin{array}{l}-0.03 \\
(-0.1)\end{array}$ & $\begin{array}{l}0.05 \\
(0.3)\end{array}$ \\
\hline Debt/Assets & & $\begin{array}{l}-5.78 \\
(-6.2)\end{array}$ & $\begin{array}{l}-5.95 \\
(-6.0)\end{array}$ \\
\hline Return on Assets & & $\begin{array}{c}0.01 \\
(0.7)\end{array}$ & $\begin{array}{l}0.01 \\
(0.6)\end{array}$ \\
\hline Book/Market & & $\begin{array}{l}-1.83 \\
(-2.1)\end{array}$ & $\begin{array}{l}-1.89 \\
(-2.1)\end{array}$ \\
\hline Extractive Indicator & & & $\begin{array}{l}-4.10 \\
(-4.2)\end{array}$ \\
\hline Manufacturing Indicator & & & $\begin{array}{l}-0.02 \\
(-0.0)\end{array}$ \\
\hline Utilities Indicator & & & $\begin{array}{l}-0.71 \\
(-0.8)\end{array}$ \\
\hline Services Indicator & & & $\begin{array}{c}0.28 \\
(0.4)\end{array}$ \\
\hline Consumer Goods Indicator & & & $\begin{array}{l}-1.64 \\
(-1.9)\end{array}$ \\
\hline$N$ & 1971 & 1465 & 1465 \\
\hline Adjusted $R^{2}$ & 0.13 & 0.18 & 0.19 \\
\hline
\end{tabular}

The regression in Column A is: Return $=\alpha+\beta_{1}$ Dividend Indicator $+\varepsilon$. The regression in Column B includes control variables and the regression in Column $\mathrm{C}$ adds industry indicator variables. All variables are defined as in table 1 except for the dividend indicator, which assumes a value of one if the firm paid a dividend within the prior year, and the industry indicator variables, which assume a value of one if the firm is in that Datastream level 3 industry code. 


\section{TABLE 3}

\section{Regression Coefficients ( $t$-statistics) for Dividend-Paying Firms Including Dividend Yield}

\begin{tabular}{|c|c|c|c|}
\hline Intercept & $\begin{array}{r}\quad \frac{\boldsymbol{A}}{7.37} \\
(36.8)\end{array}$ & $\begin{array}{r}{ }_{5.17}^{\boldsymbol{B}} \\
(4.93)\end{array}$ & $\begin{array}{r}\frac{\boldsymbol{C}}{4.98} \\
(4.1)\end{array}$ \\
\hline Div. Yield & $\begin{array}{l}-0.51 \\
(-9.3)\end{array}$ & $\begin{array}{l}-0.42 \\
(-5.8)\end{array}$ & $\begin{array}{l}-0.45 \\
(-5.4)\end{array}$ \\
\hline $\log (M V)$ & & $\begin{array}{l}0.31 \\
(2.6)\end{array}$ & $\begin{array}{c}0.32 \\
(2.6)\end{array}$ \\
\hline Debt/Assets & & $\begin{array}{r}0.13 \\
(0.2)\end{array}$ & $\begin{array}{c}0.25 \\
(0.3)\end{array}$ \\
\hline ROA & & $\begin{array}{l}-0.01 \\
(-1.1)\end{array}$ & $\begin{array}{l}-0.01 \\
(-1.0)\end{array}$ \\
\hline Book/Market & & $\begin{array}{l}-0.76 \\
(-1.2)\end{array}$ & $\begin{array}{l}-0.96 \\
(-1.4)\end{array}$ \\
\hline Extractive & & & $\begin{array}{l}-0.71 \\
(-1.1)\end{array}$ \\
\hline Manufacturing & & & $\begin{array}{l}-0.09 \\
(-0.2)\end{array}$ \\
\hline Utilities & & & $\begin{array}{c}0.75 \\
(1.3)\end{array}$ \\
\hline Services & & & $\begin{array}{c}0.83 \\
(1.7)\end{array}$ \\
\hline Consumer Goods & & & $\begin{array}{l}-0.46 \\
(-0.8)\end{array}$ \\
\hline $\begin{array}{l}N \\
R^{2}\end{array}$ & $\begin{array}{r}1244 \\
0.06\end{array}$ & $\begin{array}{r}927 \\
0.06\end{array}$ & $\begin{array}{r}927 \\
0.06\end{array}$ \\
\hline
\end{tabular}

The regression in Column A is: Return $=\alpha+\beta_{1}$ Dividend Yield $+\varepsilon$. The regression includes only dividend-paying stocks. The regression in Column B includes control variables and the regression in Column $\mathrm{C}$ adds industry indicator variables. All variables are defined as in tables 1 and 2. 
TABLE 4

Regression Coefficients ( $t$-statistics) by Dividend-Paying Firms, Including Dividend Yield Quartile

\begin{tabular}{|c|c|c|c|}
\hline Intercept & $\begin{array}{r}\quad \frac{A}{7.76} \\
(29.7)\end{array}$ & $\begin{array}{r}\quad \underline{B} \\
(5.0)\end{array}$ & $\begin{array}{c}\frac{\boldsymbol{C}}{9.98} \\
(4.1)\end{array}$ \\
\hline $2^{\text {nd }}$ Quartile & $\begin{array}{l}-1.77 \\
(-4.8)\end{array}$ & $\begin{array}{l}-1.91 \\
(-4.8)\end{array}$ & $\begin{array}{l}-1.87 \\
(-4.7)\end{array}$ \\
\hline $3^{\text {rd }}$ Quartile & $\begin{array}{l}-2.13 \\
(-5.8)\end{array}$ & $\begin{array}{l}-2.01 \\
(-4.9)\end{array}$ & $\begin{array}{l}-1.92 \\
(-4.7)\end{array}$ \\
\hline $4^{\text {th }}$ Quartile & $\begin{array}{l}-3.30 \\
(-8.9)\end{array}$ & $\begin{array}{l}-2.75 \\
(-6.4)\end{array}$ & $\begin{array}{l}-2.66 \\
(-5.7)\end{array}$ \\
\hline $\log (M V)$ & & $\begin{array}{l}0.35 \\
(2.9)\end{array}$ & $\begin{array}{l}0.37 \\
(3.0)\end{array}$ \\
\hline Debt/Assets & & $\begin{array}{c}0.55 \\
(0.8)\end{array}$ & $\begin{array}{c}0.89 \\
(1.1)\end{array}$ \\
\hline $\mathrm{ROA}$ & & $\begin{array}{c}-0.01 \\
(-0.9)\end{array}$ & $\begin{array}{l}-0.01 \\
(-0.8)\end{array}$ \\
\hline Book/Market & & $\begin{array}{l}-1.06 \\
(-1.7)\end{array}$ & $\begin{array}{l}-1.01 \\
(-1.5)\end{array}$ \\
\hline Extractive & & & $\begin{array}{l}-0.58 \\
(-0.9)\end{array}$ \\
\hline Manufacturing & & & $\begin{array}{c}0.22 \\
(0.5)\end{array}$ \\
\hline Utilities & & & $\begin{array}{c}0.34 \\
(0.6)\end{array}$ \\
\hline Services & & & $\begin{array}{c}0.98 \\
(2.1)\end{array}$ \\
\hline Consumer Goods & & & $\begin{array}{l}-0.20 \\
(-0.3)\end{array}$ \\
\hline $\begin{array}{l}N \\
R^{2}\end{array}$ & $\begin{array}{r}1244 \\
0.06\end{array}$ & $\begin{array}{r}927 \\
0.06\end{array}$ & $\begin{array}{r}927 \\
0.07\end{array}$ \\
\hline
\end{tabular}




\section{Appendix}

\section{Do Firms Eliminate E\&P and Avoid Dividend Taxation?}

This appendix reviews the empirical documentation to determine the extent to which firms exercise their options for converting dividend taxation into capital gains taxation. The three primary options are share repurchases, liquidations following taxable asset acquisitions, and special elections following stock acquisitions.

The importance of share repurchases as a source of returns to shareholders is unclear. Bagwell and Shoven (1989) report that 1987 redemptions totaled $\$ 53$ billion, up 824 percent from 1977. They show that from 1985-1987 total repurchases were 60 percent of total dividends. Auerbach and Hassett (1997) counter that redemptions have become less important. They report that by the mid-1990s, only 5-10 percent of companies repurchased shares.

Taxable asset acquisitions also provide opportunities to avoid eventual dividend taxation. Corporate liquidations typically follow asset acquisitions. In liquidations, the company terminates and distributes all assets to its shareholders and the E\&P expire. ${ }^{22}$ A shareholder is taxed at the capital gains tax rate on the difference between his liquidating distribution and his tax basis.

Taxable asset acquisitions, however, are rare. ${ }^{23}$ Typically, acquirers purchase the stock of a company, rather than its assets. Neither taxable nor tax-free stock acquisitions affect targets' E\&P.

However, acquirers can elect to eliminate the target's E\&P in stock acquisitions through provisions in Internal Revenue Code section 338 and section 338(h)(10). Effectively treating

\footnotetext{
${ }^{22} \mathrm{E} \& \mathrm{P}$ are unaffected and no capital gains tax is generated if the shareholder is a corporation owning at least 80 percent of its subsidiary's stock.

${ }^{23}$ For example, of the 83 management buyouts from 1982-1986 examined in Schipper and Smith (1991), only two reported using a taxable asset structure.
} 
stock acquisitions as asset acquisitions, the 338 election assumes acquired companies liquidate, eliminating earnings and profits, and then reincorporate. According to John Parker, then director of valuation services for Arthur Young, 338 elections eliminated E\&P in 17 of the 100 largest acquisitions from 1982-1986 or 13 percent of the dollar value of the 100 transactions (Mergers and Acquisitions, July/August 1986, p.19). Since repeal of the General Utilities doctrine in the Tax Reform Act of 1986, 338 elections are seldom tax-advantageous, even with elimination of E\&P. ${ }^{24}$ Exceptions arise when the target can avoid taxation on the difference between the fair market value of the assets and their tax bases (e.g., if the target has net operating losses). However, companies with large net operating losses likely do not have substantial E\&P. A few studies indirectly estimate the E\&P eliminated through share repurchases, taxable asset structure, and 338 elections. In their analysis of 83 going-private management buyouts from 1982-1986, Schipper and Smith (1991) report that 11 buyouts were share redemptions and 28 other acquirers announced that they would step-up the tax basis of the acquired company. Because any acquisition involving asset revaluation eliminates E\&P, at least 39 of the acquisitions eliminate E\&P and avoid dividend taxation. Thirty-four other buyouts did not revalue, and no step-up information was found in the remaining ten transactions. Consequently, E\&P were eliminated in 53 percent of the 73 private buyouts for which revaluation status was known.

Tax advisers tell us that the elimination of E\&P in going-private leveraged buyouts has increased dramatically in recent years. Wall Street consultants tell us that leveraged recapitalizations with "338(h)(10)" elections, which extinguish E\&P, have become the primary

\footnotetext{
${ }^{24}$ The General Utilities doctrine exempted from corporate taxation any gains arising from step-up of the tax basis of a target's assets to fair market value. Its repeal added a second layer of taxation to acquisitions that step-up tax basis.
} 
acquisition structure for leveraged buyouts. However, we are unaware of any empirical documentation of their structures.

Conversely, Erickson (1998) finds little evidence of E\&P elimination at acquisition among publicly-traded companies. Analyzing 340 acquisitions from 1985-1988 involving publicly traded acquirers and targets, Erickson (1998) reports only seven acquirers disclosed their intention to step-up the tax basis of the target's assets. Furthermore, he finds no link between the tax benefits from asset revaluation and the likelihood that an acquisition is taxable. Similarly, Auerbach and Reishus (1988) find no relation between the benefits of step-up and the tax status of the acquisition in their analysis of 234 acquisitions from 1969-1982. Because stepup is required for E\&P elimination, these studies suggest limited E\&P elimination at acquisition.

On the other hand, Hayn's (1989) analysis of 116 taxable acquisitions from 1970-1985 concludes that acquirers compensate target shareholders for the future tax reductions arising from asset revaluation. She reports a positive relation between the tax benefits to step-up and a target firm's announcement period returns. Her findings imply that step-up is sufficiently important to affect acquisition premiums. At a minimum, it seems likely that step-up occurs (and E\&P are eliminated) following deals where acquirers bid for the opportunity to revalue.

In summary, the evidence is conflicting about the extent to which acquisitions eliminate E\&P. ${ }^{25}$ In addition, because most studies investigate periods before the repeal of General Utilities in 1986, their findings may not generalize to the present. However, even if an acquisition leaves E\&P unaffected, dividend taxes are not inevitable. The acquisition simply perpetuates the accumulated E\&P. E\&P extinguishment may yet arise with future redemptions,

\footnotetext{
${ }^{25}$ Interestingly, none of the studies that assess the importance of revaluation on acquisitions includes an estimate of the benefits from E\&P extinguishment in their measures of the tax benefits from step-up. The exclusion is consistent with a belief that the benefits from extinguishment are either not quantifiable or trivial.
} 
taxable asset acquisitions, or stock purchases where firms elect to eliminate E\&P. At a minimum, capital gains taxation applies to shareholder distributions at liquidation and E\&P expire without triggering dividend taxation. Coupled with low dividend payouts, the potential remains for considerable share appreciation to face eventual capital gains treatment.

A casual examination of corporate histories reveals the high likelihood that companies will face an acquisition that presents an opportunity to eliminate E\&P. Fewer than 40 percent of the firms covered by Compustat in 1976 existed in 1996, the vast majority purged through acquisitions. Moreover, most of these acquisitions provided an opportunity to eliminate E\&P. Sampling firms covered by Accounting Trends and Techniques, we find that a stable 90-92 percent of acquisitions from 1976-1996 used the purchase method of accounting for GAAP purposes. E\&P elimination is possible for any acquisition using purchase accounting because both taxable asset acquisitions and taxable stock acquisitions that elect $\mathrm{E} \& \mathrm{P}$ elimination use purchase accounting. Unfortunately, the publicly available financial statements do not provide more specific information about E\&P elimination at acquisition.

In summary, share repurchases, taxable asset acquisitions, and taxable stock acquisitions electing asset revaluation provide opportunities to extinguish $\mathrm{E} \& \mathrm{P}$ and avoid eventual dividend taxation. The evidence suggests that these options are used; however, their frequency is unclear. Unfortunately, the empirical documentation predates the period examined in the paper by nearly a decade. However, lacking contrary evidence, it seems reasonable to assume that substantial portions of corporate value could avoid dividend taxation and be taxed as capital gains. 